\title{
Wild Herbivore Forage Preferences in Semi-Natural Mountain Hay-Meadows
}

\author{
Adrian GLIGA ${ }^{1 *}$, Dumitrița DASCĂLU ${ }^{1}$ \\ ${ }^{1}$ Department of Engineering and Environmental Protection, Faculty of Agriculture, University of Agricultural \\ Sciences and Veterinary Medicine Cluj-Napoca, Calea Manastur, no.3-5, 400372, Cluj-Napoca \\ *corresponding author: adrian.gliga@usamvcluj.ro
}

Bulletin UASVM series Agriculture 77(2) / 2020

Print ISSN 1843-5246; Electronic ISSN 1843-5386

DOI:10.15835/buasvmcn-agr: 2020.0038

\begin{abstract}
In the context of increasing grassland abandonment we observed wild herbivore impact on the vegetation in order to understand their influence. To quantify semi-natural grassland usage by wild herbivores, we determined grazing intake in semi-natural hay-meadows surrounded by forest vegetation. Grazing exclusion cages were placed at three locations in the Valea Mare village area situated in Bistrița-Năsăud County, Romania, from 1 April 2014 5 October 2014. Sampling took place at two times during this period, first shortly before the hay meadows were mowed and second at the end of the vegetation growing season. Herbage air dry matter yield was measured using two types of observation plots (cage protected plots and unprotected plots). Plant composition on the studied hay-meadows was analyzed using PC-ORD (in order to explain the preference of herbivores for each location. Although herbage production did not vary significantly between locations, the herbage intake of total dry matter production did vary between locations. Wild animals grazed through the entire growing season and based upon the floristic composition analyses we explained differences in herbage intake based on plant species preference. The management of these meadows maintains an offer of good quality forage throughout summer, and the forest surrounding grasslands provides cover when needed. In order to inhibit woody vegetation and to conserve speciesrich open landscape further observation need to be made about the optimal deer species densities.
\end{abstract}

Keywords: exclusion cage, forage intake, preference, semi-natural grassland, wild ungulates

\section{INTRODUCTION}

In many parts of the world, vertebrate herbivores influence the structure, composition and functioning of ecosystems (Augustine and McNaughton, 1998). Despite the fact that at the global level, half the planet's wildlife population has declined since 1970, this trend is not homogeneous across species and areas (Riccioli et al., 2019).

Hay meadows currently comprise 10.4\% (460 $011 \mathrm{ha}$ ) of Romania's agricultural land and their area shows a slightly increasing trend (National Institute of Statistics, 2010). Semi-natural hay meadows, used by grazing herbivores, are important for a variety of agricultural, hunting, recreational and conservation purposes in Romania and elsewhere in the world. Typically, there is little quantitative evidence for the magnitude of grazing impacts by herbivores on these grassland habitats to inform their management (Albon et al., 2007).

In Central Europe, open semi-natural habitats such as hay meadows, with their characteristic species-rich communities, have become rare over thelastfew decades. Thisisa result ofabandonment, afforestation, nitrogen deposition and changing land use (Jentsch and Beyschlag, 2003). Effective management strategies are needed to ensure the survival of such communities and species (Warren et al., 2007; Jentsch et al., 2008). This includes the traditional management practices of open habitats include clearing, mowing, extensive grazing with 
domestic animals, and the use of fire (Jentsch et al., 2008).

More recently, the 'new wilderness concept' claims that free-ranging wild herbivore assemblages can create open, nutrient-poor habitats as part of a shifting successional mosaics (Vera, 2000; Bokdam, 2003). Modeling approaches (Weber et al., 2008) and field studies (Senn and Suter, 2003) in different parts of the world support this approach and have consistently showed the potential of wild ungulates to control the abundance of woody species (MacDougall, 2008). Grazing affects plant species diversity through mechanisms that influence local plant colonization and extinction dynamics (Olff and Ritchie, 1998). Herbivores can reduce vegetation biomass (Vallentine, 2001) and disturb the soil by trampling (Collins and Glenn, 1988). Recent studies on management and restoration by grazing are equivocal (Van Wieren and Bakker, 2008) and have revealed both an increase in species richness, accompanied by a decrease of tall dominant species (Hejcman et al., 2008; Pavlu et al., 2007), as well as a decrease in species richness (Bullock et al., 2001). It is important to resolve when and where herbivores impact species richness in grassland vegetation. Previous studies have investigated the impact of domestic herbivores, but not wild herbivores. Domestic animals are less effective in controlling woody plant cover because of the general preference for graminoids and herbs (Hoffmann et al., 2005). However, grasslands that are further away from the forest border are less exposed, for example, to grazing by wild deer (Trdan and Vidrih, 2008).

Wild herbivore species like red deer are rapidly expanding in many European countries, and this, in combination with the abandoning of agriculture and the depopulation of mountain regions, will increase the presence of the species into rural areas (Marchiori et al., 2012). Wild herbivore grazing could have a positive effect on keeping these meadows open due to their feeding behavior, in the context of abandonment; therefore their populations must be carefully managed according to their habitat carrying capacity.

In this study we experimentally assess the impacts of wild ungulate herbivores on hay meadow vegetation in the mountains of northern Romania. Specific objectives were to estimate whether grassland production or grassland herbi- vore intake varied among locations. We expected higher intake where there was a greater abundance of palatable plant species and we use this to explain their preferences at each location. In order to explain this phenomenon we quantified the productions of these semi-natural grasslands, the intake at each location and also characterized the floristic composition for each location. Such data was used to help identify the role of wild animals in this habitat and provide a basis for further studies of interactions of wild herbivores in seminatural hay meadows vegetation.

\section{MATERIALS AND METHODS}

The studies were conducted in the village area of Valea Mare, in the North-Eastern part of Bistrita - Năsăud County in the 2014 growing season. We chose three locations, with the local names: Arin

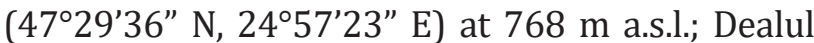
Negru (47 $\left.30^{\prime} 35^{\prime \prime} \mathrm{N}, 24^{\circ} 58^{\prime} 1^{\prime \prime} \mathrm{E}\right)$ at $916 \mathrm{~m}$ a.s.l. and

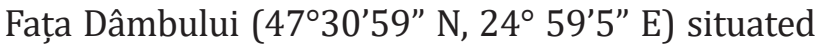
at $1261 \mathrm{~m}$ a.s.l.. We chose these locations because they were isolated from recent human impacts and because they were surrounded by forest vegetation.

The surrounding vegetation was characterized by the presence of beech and spruce (Leucanthemo waldsteinii - Piceio - Fagetum, Soó 1964) forest. On the cleared hillsides of this sublevel, mesophilic phytocoenosis from the association Festuco rubrae - Agrostetum capillaris (Horvat, 1951) has established, being the predominant grassland type in the mountain meadows in this region (Coldea, 1990). The average annual temperature is $1.3^{\circ} \mathrm{C}$ and precipitation varies between $1200-1400 \mathrm{~mm}$ year-1.

Red deer (Cervus elaphus L.) and roe deer (Capreolus capreolus L.) were the main wild animals in the study area. According to the administration of the local hunting range, these species have the following densities: red deer 0.55 individuals $\mathrm{km}^{-2}$ and roe deer 0.39 individuals $\mathrm{km}^{-2}$.

In each location, 5 cages were placed at the beginning of the experiment and used to represent "protected" observations. The protected vegetation was mowed when herbage sampling took place. The second observation was "unprotected" (cages were placed at the date of herbage sampling), and the vegetation under them was mowed on the day of each sampling (Trdan and Vidrih, 2008).

The first sampling was made approximately one week before farmers mowed the hay meadows, 
during the second ten-day period of July. Last sampling was in the first ten-day period of October at the end of the vegetation period.

In order to assess grassland vegetation reduction from intake at these locations we used cylindrical cages ( $1 \mathrm{~m}^{2}$ surface area and $1.5 \mathrm{~m}$ high) built from metallic mesh. Cages were placed and anchored in a line at each location during spring, 20 to $50 \mathrm{~m}$ from a forest border and 15 to $20 \mathrm{~m}$ apart from each other in the field during spring, before snow melted. Wild ungulates did not have access within these exclusions.

At each sampling date, herbage under the cages was mowed with a hand scissor at 4-5 cm height. The same procedure was followed for a sample area of $1 \mathrm{~m}^{2}$ chosen at a distance of 1-2 m from the cages. Herbage dry matter (DM) yield was determined as oven dried mass after drying at $110^{\circ} \mathrm{C}$ and weighing. The intake was determined as the difference in the amount of DM from the two types of observations.

We determined the floristic composition and the medium abundance-dominance of these haymeadows using an improved Braun-Blanquet (Braun-Blanquét, 1932) scale with subdivisions (Păcurar and Rotar, 2014) applied to an area of $25 \mathrm{~m}^{2}$ per survey using species lists compiled for this study. Five floristic surveys were performed at each location at the sampling date, in the vicinity of the protection cages. In order to explain wild herbivore preferences we used a nine gradient scale (Kühn and Klotz, 2002) in which 1 represents plant species that are not or very little used by wild herbivores and 9 plant species with a high favorability by wild herbivore.

Floristic composition, herbage yield and intake analysis were performed using PC-ORD (version 6). This program focuses on nonparametric tools, on graphics, randomization tests, bootstrapped confidence intervals for analysis of community data (McCune and Grace, 2011). In order to process and interpret grassland yield data and herbage intake we used box plot analysis and Tukey test to point out production and intake differences between stations. We used principal coordinate analisys (PCoA) for the explanation of location preferability under the influence of the environment factors.

\section{RESULTS AND DISCUSSIONS}

Dry matter (DM) productions, resulting from sampling data, differ slightly from one site to another, thus: Arin location yield was 3.92 t DM $\mathrm{ha}^{-1}$, the Dealul Negru location totaled 4.04 t DM ha $^{-1}$ and the total production in Fata Dambului location was $3.70 \mathrm{t} \mathrm{DM} \mathrm{ha}^{-1}$ (Table 1) the lowest compared to the other two locations (Fig.1). Tukey test showed no production differences bet-

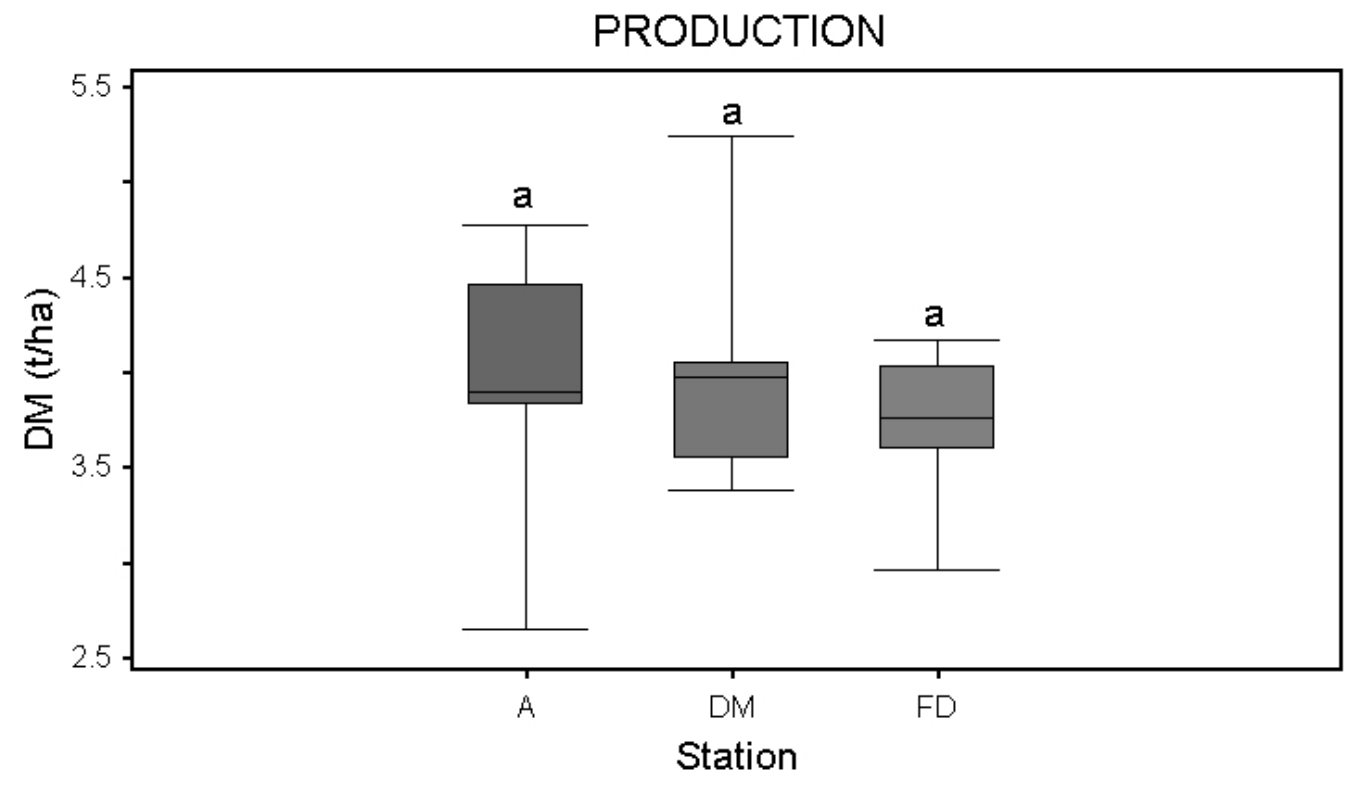

Figure 1. Herbage dry matter yield in the three studied locations (A- Arin location, DN- Dealul Negru location, FD- Fața Dâmbului location) 
Table 1. Precentage of species groups present in the sward of each location

\begin{tabular}{lccc}
\hline \multicolumn{1}{c}{ Station / Botanical families } & Arin (\%) & Dealul Negru (\%) & Fata Dambului (\%) \\
\hline Poacee & 42,9 & 49,55 & 38,75 \\
\hline Cyperaceae and Juncaceae & 1 & 2,6 & 25,8 \\
\hline Fabacee & 20,45 & 20,35 & 16,55 \\
\hline Other botanical families (OBF) & 38,25 & 23,46 & 15,11 \\
\hline
\end{tabular}

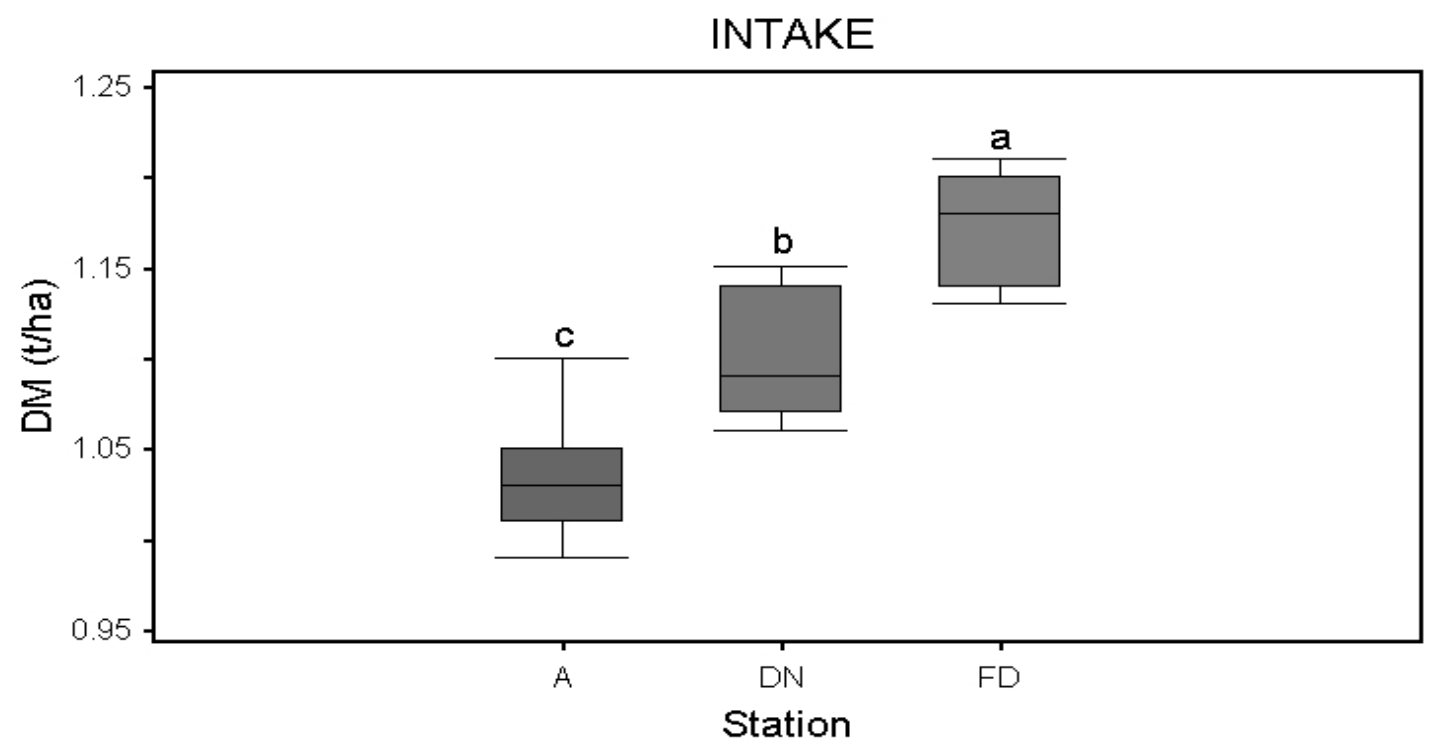

Figure 2. Herbage dry matter intake at each studied location (A- Arin location, DN- Dealul Negru location, FD- Fața Dâmbului location)

ween locations, as it can be seen in the graphic representation from Fig.1.

Arin location, had the lowest intake of 1.04 t DM ha ${ }^{-1}$, representing $26.4 \%$ of the total yield. There was a consumption of $1.10 \mathrm{tDM} \mathrm{ha}^{-1}$ at Dealul Negru location totaling $27.28 \%$ of the production. The intake from Fata Dambului location was 1.15 t DM ha ${ }^{-1}$, and accounted for $31.1 \%$ of the total grassland production (Table 1) and it was also the highest of the three locations. Tukey test showed significant intake differences between locations as shown in Fig. 2.

PCoA explained $78 \%$ of the variation in floristic composition with $62 \%$ and $16 \%$ explained by Axis 1 and Axis 2 respectively (Fig.3). The Fata Dambului location grassland was identified as Festuca rubra L. - Agrostis capillaris L. type whereas Dealul Negru and Arin locations were a Agrostis capillaris L. - Festuca rubra L. type.
High herbage intake on Festuca rubra L. Agrostis capillaris L. grassland from Fata Dambului were explained by the high proportion of grasses (Poaceae, Cyperaceae and Juncaceae) in the vegetation (Fig. 3; Table 1; Appendix 1). Also the increased weight of species category with favorability index 9 (F.I.9) influenced plant site preferences (Fig. 3). High species richness, a dominance of low value Poaceae (LV_P) for wild herbivore preferred species, and the high percentage of species category with 5 to 6 favorability indices (F.I.5-6) but with high abundance, are correlated with the high intake at this station (Fig. 3).

The Agrostis capillaris L. - Festuca rubra L. phytocoenosis from Dealul Negru location had a lower intake rate than the Fata Dambului location. This can be explained primarily by the lower proportion of grasses (Poaceae, Cyperaceae and 
Juncaceae) in the vegetation (Table 1; Appendix 1 ). The high proportion of species category with favorability indices from 7 to 8 the F.I.7-8 had a strong influence on site preference (Fig. 3). However the high proportion of Poaceae (Table 1) and high value indices for wild herbivore preferences are correlated with intake at this station (Fig. 3).
The low intake from the same grassland type (Agrostis capillaris L. - Festuca rubra L.), at the Arin location can also be explained by the even lower proportion of grasses (Poaceae, Cyperaceae and Juncaceae) in the vegetation than at the other two stations (Table 2; Appendix 1). Species categories with favorability indices from 1 to 4 (F.I.1-2) and (F.I.3-4) were more often correlated with intake

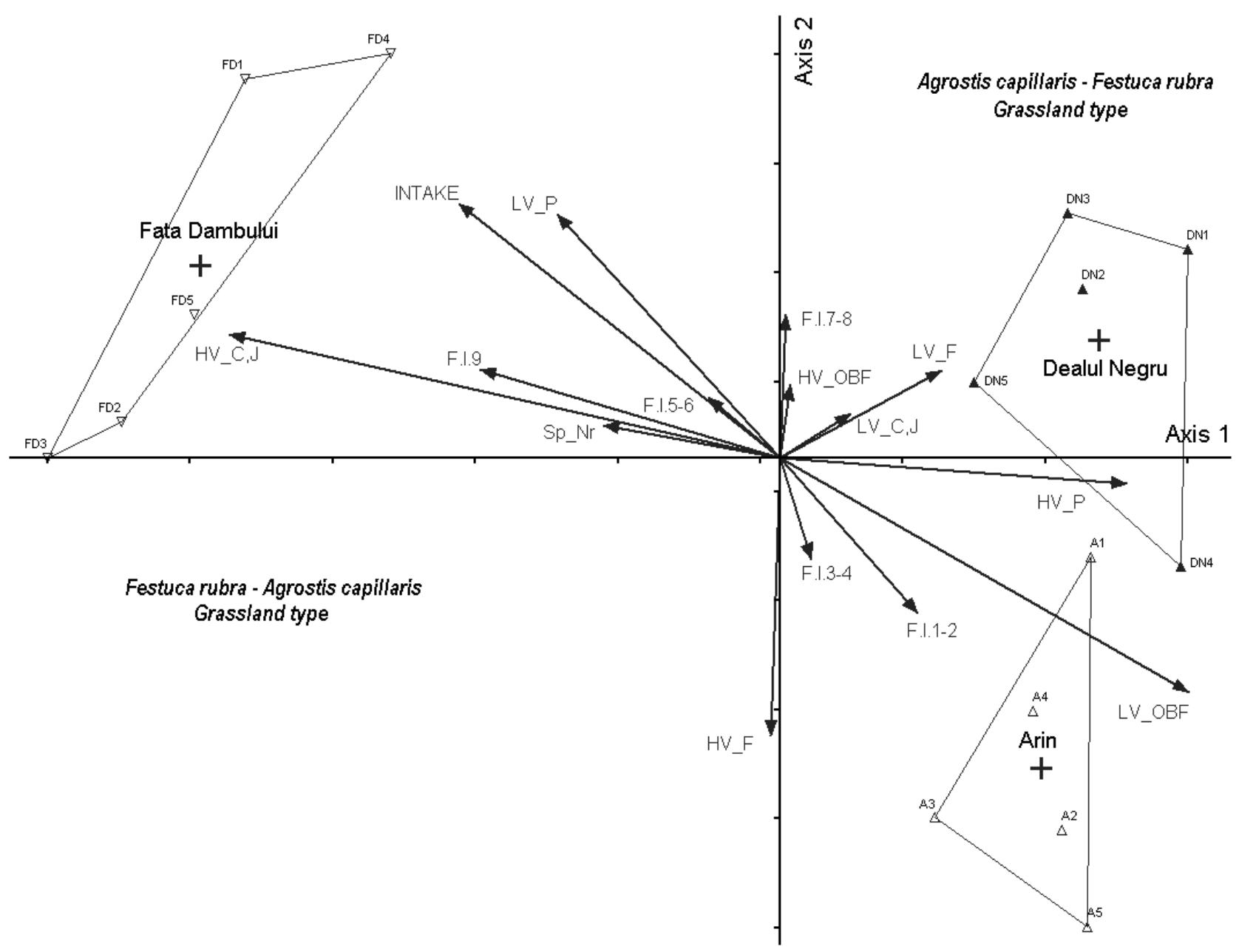

Figure 3. Ordination diagram from principal coordinates analysis (PCoA). The compozition dataset was based on cover values per plot by species. Bray-Curtis distance was used for the ordination (iteration for 3 dimensions). We have chosen axes 1 with 2 for the presentation of the results. Symbols represent individual plots coded by vegetation type that are further delimited with polygons. The arrows represent the explanatory variables fitted onto the ordination (HV_P = high value Poaceae, HV_F= high value Fabaceae, HV_C,J= high value Cyperaceae and Juncaceae, $\mathrm{HV} \_\mathrm{OBF}=$ high value other botanical families, $\mathrm{LV} \_\mathrm{P}=\mathrm{low}$ value Poaceae, LV_F= low value Fabaceae, LV_C,J= low value Cyperaceae and Juncaceae, LV_OBF= low value other botanical families, Sp_Nr= species number, INTAKE= grassland reduction values, F.I.1-2= favorability index from parametre 1 to parameter 2, F.I.3-4= favorability index from parametre 3 to parameter 4, F.I.5-6= favorability index from parametre 5 to parameter 6, F.I.7-8= favorability index from parametre 7 to parameter 8, F.I.9= favorability index, parametre 9). Polygons delimit the grassland types (Festuca rubra L. - Agrostis capillaris L. from Fata Dambului station and Agrostis capillaris L. - Festuca rubra L. from Arin and Dealul Negru station). 


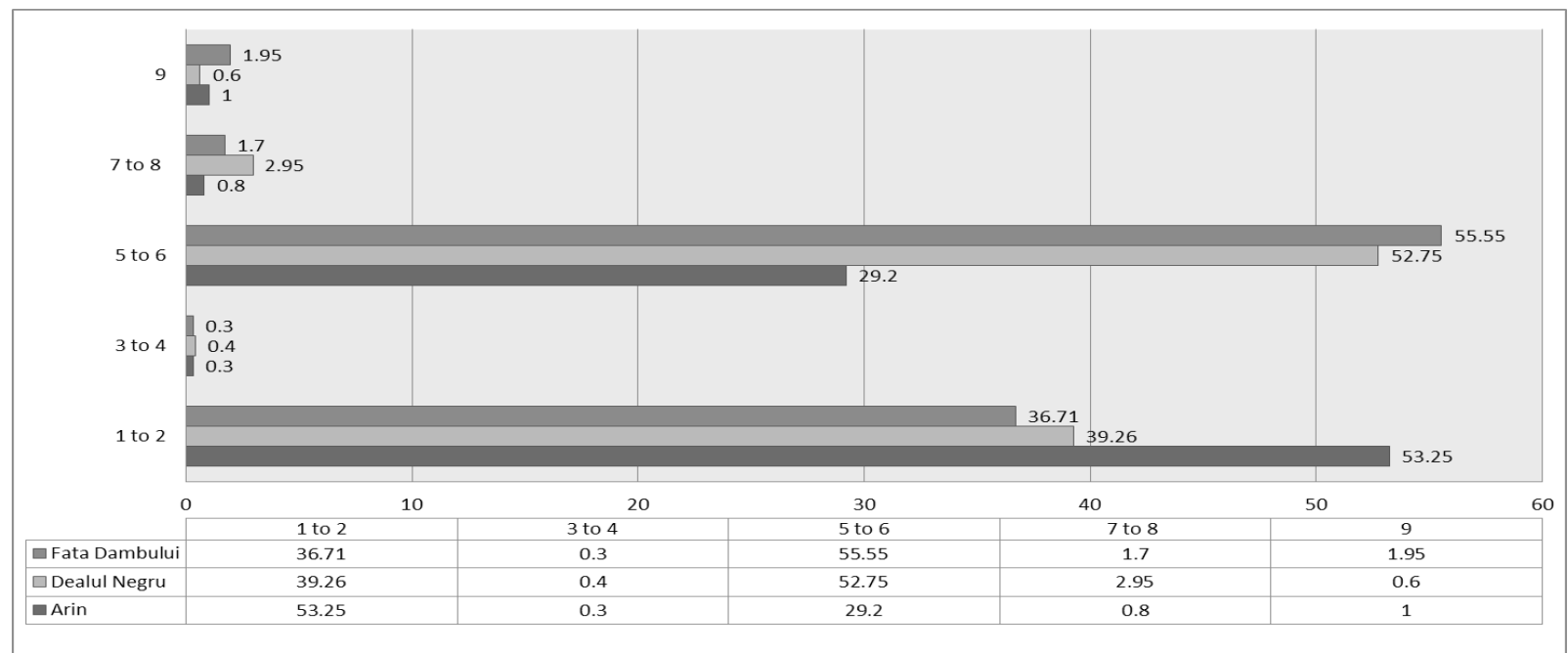

Figure 4. Favorability spectrum of plant species by wild herbivore according on the three stations.

Table 2. High and low value plant species and their favorability indices (Kühn and Klotz, 2002)

\begin{tabular}{clcl}
\hline $\begin{array}{c}\text { Favorability } \\
\text { index }\end{array}$ & \multicolumn{1}{c}{ High value } & Low value \\
\hline 9 & Achillea millefolium & $\begin{array}{c}\text { Favorability } \\
\text { index }\end{array}$ & Species \\
\hline 9 & Dechampsia flexuosa & 3 & Anthoxanthum odoratum \\
\hline 9 & Rumex acetosa & 3 & Ecvisetum palustre \\
\hline 9 & Vicia cracca & 3 & Silene vulgaris \\
\hline 8 & Campanula rotundifolia & 2 & Carex pallescens \\
\hline 8 & Dactilis glomerata & 2 & Cynosurus cristatus \\
\hline 8 & Phleum pratense & 2 & Festuca rubra \\
\hline 7 & Fragaria vesca & 2 & Potentilla erecta \\
\hline 7 & Viola canina & 2 & Prunella vulgaris \\
\hline 6 & Agrostis capillaris & 2 & Ranunculus bulbosus \\
\hline 6 & Trifolium repens & 2 & Veronica chamaedrys \\
\hline 5 & Calamagrostis varia & & \\
\hline 5 & Leontodon autumnalis & & \\
\hline 5 & Leontodon hispidum & & \\
\hline 5 & Lotus corniculatus & & \\
\hline 5 & Luzula campestris & & \\
\hline 5 & Stellaria graminea & & \\
\hline 5 & Trifolium pratense & & \\
\hline & & & \\
\hline
\end{tabular}


at this location. Also the high presence of species from other botanical family groups with low values for wild herbivore preferences, are correlated with the low intake at this station (Fig. 3).

Differences in intake among locations (Fig. 2) are clearly reflected in the differences in plant favorability among locations (Fig. 4). At Arin station plants with favorability indices ranging between 1 and 2 had the highest coverage of $53.25 \%$ compared to other stations that had coverages from $39.26 \%$ at Dealul Negru to $36.71 \%$ at Fata Dambului station (Fig. 4). Plants with indices between 3 and 4 had very low coverage, with $0.4 \%$ at Dealul Negru and $0.3 \%$ at the other two stations (Fig. 4).

The coverage of plants with indices between 5 and 6 were $29.2 \%$ at Arin station and coverage at Dealul Negru was $52.75 \%$ and $55.55 \%$ at Fata Dambului (Fig. 4). Plant species with a degree of favorability between 7 and 8 have coverage of $0.8 \%$ in the Arin station, Dealul Negru station had 2.95\% coverage and Fata Dambului station 1.7\% of total coverage. Species with 9 favorability index occupied $1.95 \%$ of the sward on Fata Dambului station, $0.6 \%$ on Dealul Negru station and $1 \%$ on Arin station (Fig. 4).

This study confirms that wild herbivores have aninfluenceonforageintakeonmountain meadows. The effects observed in this study are likely the result of a series of combined circumstances: the management of these meadows maintains an offer of good quality forage throughout summer, and the forest surrounding grasslands provides cover when needed. Therefore, the findings of this study cannot be generalized to other areas where herbivore density is different and human disturbance is stronger.

Although DM yields did not differ significantly between locations, DM intake showed significant differences between the three locations. The high coverage percentage of Poaceae, Cyperaceae and Juncaceae of the sward had a positive influence on herbage intake. From the species found in grassland vegetation, these three botanical families represent a favorite food for deer species (Obidziński A. et al., 2013). Yield loses varied between locations from $26.4 \%$ to $31.1 \%$. Other studies show a greater yield reduction in similar conditions but with higher herbivore densities (Trdan and Vidrih, 2008).

A number of studies show that cervides prefer Agrostis capillaris L. - Festuca rubra L. productive grasslands (Clutton-Brock and Albon, 1989) and show largely the same preferences toward grasses (Prokešová, 2004; Suter et al., 2004; Obidziński et al., 2013). Although males consume a higher proportion of species with low forage value than females (Staines et al., 1982).

High grazing pressure by deer suppresses forest regeneration, both by severely reducing seedling density and by delaying growth of the few remaining survivors (Putman et al. 1989; Nixon and Cameron, 1994) and contributes in maintaining short vegetation (Majid I. et al., 2011), the favorite food of females.

Current evidence indicates that deer populations need to be in the range of $4-7 \mathrm{~km}^{-2}$ in the uplands to ensure adequate regeneration and maintain plant diversity (Gill, 2000). Wild ungulate browsing is a useful tool to inhibit encroachment of woody vegetation and to conserve a species-rich, open landscape (Tschöpe, 2011). However the low densities in our study area will most likely not be able to sustain open grasslands and successional changes will appear.

\section{CONCLUSIONS}

According with our results, we observed the following aspects:

Consumption by wild herbivores followed the same pattern, increasing with increasing altitude. The sward structure and its evolution regarding the preferability of wild herbivores over the species encountered correlates positively with this gradient;

The share of grassland species that gave the ecological character of phytocenoses were directly correlated with the consumption achieved;

With regard to the development of grassland conservation strategies in the study area or similar areas with the same climatic and environmental conditions, we recommend a considerable increase in deer species populations, as the modest population encountered during the study period do not have a sufficiently high impact to keep the meadow surfaces open.

\section{REFERENCES}

1. Albon, S. D., Brewer, M. J., O'brien, S., Nolan, A. J., Cope, D. (2007). Quantifying the grazing impacts associated with different herbivores on rangelands. Journal of Applied Ecology, 44(6), 1176-1187.

2. Allen RB, Forsyth DM, Allen RKJ, Affeld K, MacKenzie DI. "Solar Radiation Determines Site Occupancy of Coexisting 
Tropical and Temperate Deer Species Introduced to New Zealand Forests." PloS one 10.6 (2015): e0128924.

3. Augustine, D.J. and McNaughton, S.J. (1998) Ungulate effects on the functional species composition of plant communities: herbivore selectivity and plant tolerance. Journal of Wildlife Management, 62, 1165-1183.

4. Bokdam, J. (2003) Nature conservation and grazing management. Free-ranging cattle as a driving force for cyclic succession. Dissertation. University of Wageningen, The Netherlands.

5. Braun - Blanquét J., (1932). Plant Sociology, the study of plant communities, Ed. Mc-Graw - Hill Book Company, Inc. New - York and London, 31-33

6. Bullock, J.A., Franklin, J., Stevenson, M.J., Silvertown, J., Coulson, S.J., Gregory, S.J. and Tofts, R. (2001). A plant trait analysis of responses to grazing in a long-term experiment. Journal of Applied Ecology 38: 253-267.

7. Clutton-Brock, T.H., Albon, S.D. (1989) Red Deer in the Highlands. BSP Professional Books, Oxford, UK.

8. Coldea Gh., (1990): Muntii Rodnei. Studiu geobotanic, Edit. Academiei Române, Bucuresti.

9. Collins, S.L. and Glenn, S.M. (1988). Disturbance and community structure in North American Prairies. In: During, H.J., Werger, M.J.A., Willems, J.H. (eds.) Diversity and pattern in plant communities. pp. 131 141. SPB Academic Publishing, The Hague, NL.

10. Gębczynska Zofia. "Food of the roe deer and red deer in the Białowieża Primeval Forest." Acta Theriologica 25.40 (1980): 487-500.

11. Gill, Robin. The impact of deer on woodland biodiversity. No. 36. Forestry Commission, 2000.

12. Hejcman, M., Zakova, I., Bilek, M., Bendova, P., Hejcmanova, P., Pavlu, V., Stranska, M. (2008). Sward structure and diet selection after sheep introduction on abandoned grassland in the Giant Mts, Czech Republic. Biologia 63: 506-514.

13. Hoffmann, M., Cosyns, E., Lamoot, I. (2005). Large herbivores in coastal dune management: do grazers do what they are supposed to do? In: Herrier, J., Mees, J., Salman, A., Seys, J., Van Nieuwenhuyse, H. and Dobbelaere, I. (eds.) Proceedings "Dunes and Estuaries 2005": International Conference on nature restoration practices in European Coastal habitats. VLIZ Special Publication 19. pp. 249-267. Vlaams Instituut Voor De Zee, Oostende, BE.

14. Iravani, M., Schütz, M., Edwards, P. J., Risch, A. C., Scheidegger, C., Wagner, H. H. (2011). Seed dispersal in red deer (Cervus elaphus L.) dung and its potential importance for vegetation dynamics in subalpine grasslands. Basic and Applied Ecology, 12(6), 505-515.

15. Jentsch, A. and Beyschlag, W. (2003). Vegetation ecology of acidic grasslands in the lowland area of central Europe. Flora 198: 3-25.

16. Jentsch, A., Friedrich, S., Steinlein, T., Beyschlag,W. and Nezadal, W. (2008). Assessing conservation action for substitution of missing dynamics on former military training areas in Central Europe. Restoration Ecology 17: 107-116.

17. Kühn, I., Klotz, S. (2002): Systematik, Taxonomie und Nomenklatur. In: Klotz, S., Kühn, I. and Durka, W. (Hrsg.): BIOLFLOR - Eine Datenbank mit biologisch-ökologischen
Merkmalen zur Flora von Deutschland. Schriftenreihe für Vegetationskunde. Bonn.

18. MacDougall, A.S. (2008). Herbivory, hunting, and longterm vegetation change in degraded savanna. Biological Conservation 141: 2174-2183.

19. Marchiori, Elisa, Enrico Sturaro, and Maurizio Ramanzin. (2012), "Wild red deer (Cervus elaphus L.) grazing may seriously reduce forage production in mountain meadows." Italian Journal of Animal Science 11.1: 9.

20. Nixon, C. and E. Cameron (1994) "A pilot study on the age structure and viability of the Mar Lodge pinewoods." Scottish Forestry (United Kingdom) .

21. Obidziński, A., Kiełtyk, P., Borkowski, J., Bolibok, L., Remuszko, K. (2013). Autumn-winter diet overlap of fallow, red, and roe deer in forest ecosystems, Southern Poland. Central European Journal of Biology, 8(1), 8-17.

22. Olff, H., Ritchie, M.E. (1998). Effects of herbivores on grassland plant diversity. Trends in Ecology and Evolution 13: 261-265.

23. Păcurar, F., Rotar, I., Metode de studiu și interpretare a vegetației pajiștilor, Ed. Risoprint, Cluj-Napoca (2014), ISBN 978-973-53-1452-1.

24. Pavlu, V., Hejcman, M., Pavlu, L., Gaisler, J. (2007). Restoration of grazing management and its effect on vegetation in an upland grassland. Applied Vegetation Science 10: 375-382.

25. Prokešová, Jarmila. "Red deer in the floodplain forest: the browse specialist." Folia Zool 53.3 (2004): 293-302.

26. Petrak, M., (1982): Etho-ökologische Untersuchungen an einer Rothirsch Population (Cervus elaphus Linné, 1758) der Eifel unter besonderer Berücksichtigung des stoffwechselbedingten Verhaltens. Schrift. Arbeitskreis Wildbiol. Und Jagd-wiss. Univ. Gießen, H.10, 1-196.

27. Putman R. J., Edwards P. J., Mann J. C. E., How R. C. and Hill S. D., "Vegetational and faunal changes in an area of heavily grazed woodland following relief of grazing." Biological Conservation 47.1 (1989): 13-32.

28. Riccioli Francesco, Boncinelli Fabio, Fratini Roberto, El Asmar Jean Piere and Casini Leonardo 2019. Geographical Relationship between Ungulates, Human Pressure and Territory. APPLIED SPATIAL ANALYSIS AND POLICY, 12, 4: 847-870.

29. Senn, J. and Suter, W. (2003). Ungulate browsing on silver fir (Abies alba) in the Swiss Alps: beliefs in search of supporting data. Forest Ecology and Management 181: 151-164.

30. Suter, W., Suter, U., Krüsi, B., \& Schütz, M. "Spatial variation of summer diet of red deer Cervus elaphus in the eastern Swiss Alps." Wildlife biology 10.1 (2004): 43-50.

31. Staines, B.W., Crisp, J.M. and Parish, T. (1982) Differences in the quality of food eaten by red deer Cervus elaphus stags and hinds in winter. Journal of Applied Ecology, 19, 65-77.

32. Trdan, S., and Vidrih, M. (2008). Quantifying the damage of red deer (Cervus elaphus) grazing on grassland production in southeastern Slovenia. European Journal of Wildlife Research, 54(1), 138-141.

33. Tschöpe Okka, Wallschläger Dieter, Burkart Michael, Tielbörger Katja. (2011): "Managing open habitats by wild ungulate browsing and grazing: A case-study in 
North-Eastern Germany." Applied Vegetation Science14.2 200-209.

34. Vallentine, J.F. (2001). Grazing management. 2nd ed. Academic Press, London, UK.

35. Van Wieren, S.E. and Bakker, J.P. (2008). The impact of browsing and grazing herbivores on biodiversity. In: Gordon, I.J. and Prins, H.H.T. (eds.) The ecology of browsing and grazing. pp. 263-292. Springer, Berlin, DE.

36. Vera, F.W.M. (2000). Grazing ecology and forest history. CABinternational, Wallingford, CT, US.

37. Warren, S.D., Holbrook, S.W., Dale, D.A., Whelan, N.L., Elyn, M., Grimm, W. and Jentsch, A. (2007). Biodiversity and the heterogeneous disturbance regime on military training lands. Restoration Ecology 15: 606-612.

38. Weber, P., Rigling, A. and Bugmann, H. (2008). Sensitivity of stand dynamics to grazing in mixed Pinus sylvestris and Quercus pubescens forests: amodelling study. Ecological Modelling 210: 301-311.

39. Wittig, R. (2012). Geo-botanik. Ed. Böhlau. ISBN 978-38252-3753-0.

40. ***http: / / www.insse.ro/cms / files / RGA2010/ Rezultate\%20definitive\%20RGA\%202010/rezultate\%20 definitive\%20RGA\%202010.htm 